\title{
АМНИСТИЯ КАК ВИД ОСВОБОЖДЕНИЯ ОТ УГОЛОВНОЙ ОТВЕТСТВЕННОСТИ ЗА ПРЕСТУПЛЕНИЯ В СФЕРЕ ЭКОНОМИЧЕСКОЙ ДЕЯТЕЛЬНОСТИ
}

\begin{abstract}
Аннотация: Статья посвящена анализу так называемой «экономической амнистии» как вида освобождения от уголовной ответственности за преступления в сфере экономической деятельности. выявляются общие признаки амнистии как вида освобождения от уголовной ответственности и проводится их приложение к преступлениям в сфере экономической деятельности. На основе анализа практики применения постановления об объявлении амнистии показываются проблемы, связанные с формулированием в постановлении и реальным выполнением условий амнистии, в особенности связанные с таким обстоятельством, как возмещение причинённого вреда. Анализируется также общая изелевая направленность акта об амнистии Статья построена на использовании сочиологического и формально-юридического метода в анализе практики применения амнистии. Использован также статистический метод для оценки эффективности амнистии. Практика применения акта об амнистии показала её несовершенство в части определения условий амнистии, их процессуальной реализации на досудебных и судебных стадиях уголовного процесса. В будущем использование амнистий подобного рода нецелесообразно, следует совершенствовать уголовный закон в направлении гуманизаџии санкций статей Особенной части УК РФ и правоприменение в направлении исключения судебных ошибок.
\end{abstract}

Abstract: The article is devoted to the analysis of the so-called "economic amnesty" as the type of dismissal from criminal responsibility for the crimes in the economic sphere. The author singles out the general characteristics of amnesty as a type of dismissal from criminal responsibility, providing analysis of its application to the economic crimes. Based upon the analysis of the practice of application of the decree on the amnesty, the author shows the difficulties regarding legal formulae and de facto implementation of the amnesty conditions, especially those concerning compensation of the damage. The author analyzes the general targets of the amnesty. The article is based upon the use of sociological and formal legal methods in the analysis of the practice of amnesty application. The author also used statistical method in order to evaluate amnesty efficiency. The practice of application of amnesty has shown its imperfections in part of defining the conditions for the amnesty, their procedural implementation at the pre-trial and trial stages of the criminal process. In the future the use of such amnesties seems unviable, rather, the criminal law should be amended to make some sanctions in the Articles of the Special Part of the Criminal Code of the Russian Federation more humane, and the legal practice should be corrected in order to avoid judicial mistakes.

Ключевые слова: Амнистия, преступление, сфера экономической деятельности, освобождение, уголовная ответственность, возмещение ущеерба, приниип гуманизма, состав преступления, правила игры, заказные дела. Keywords: Amnesty, crime, sphere of economic activity, freeing, criminal responsibility, compensation of damage, principle of humanism, elements of a crime, rules of a game, "pre-ordered" cases.

свобождение от уголовной ответственности за преступления в сфере экономической деятельности, до 2013 г. развивавшееся исключительно на законотворческом уровне за счёт включения в УК РФ специальных примечаний к статьям Особенной части (Федеральный закон от 29 декабря 2009 г. № 383-Ф3 «О внесении изменений в часть первую Налогового кодекса Российской Федерации и отдельные законодательные акты Российской Федерации» ${ }^{1}$ ) и создания общей нормы ст. $76^{1}$ УК РФ (Федеральный закон от 7 декабря 2011 г. № 420-Ф3 «О

${ }^{1}$ Собрание законодательства РФ. 2010. № 1. Ст. 4. внесении изменений в Уголовный кодекс Российской Федерации и отдельные законодательные акты Российской Федерации»²), в том же году получило новый импульс в своём развитии уже на правоприменительном уровне. Постановлением Государственной Думы Федерального Собрания РФ от 2 июля 2013 г. № 2559-6 ГД «Об объявлении амнистии» была объявлена так называемая «экономическая амнистия».

Инициатива в её объявлении принадлежала Уполномоченному при Президенте РФ по защите

\footnotetext{
${ }^{2}$ Собрание законодательства РФ. 2011. № 50. Ст. 7362.

${ }^{3}$ Собрание законодательства РФ. 2013. № 27. Ст. 3558.
} 
прав предпринимателей Б. Ю. Титову. Впервые эта идея была озвучена им ещё в 2012 г., однако зримые очертания стала приобретать только весной 2013 г. Б. Ю. Титов предложил объявить амнистию бизнесменам, осужденным за экономические преступления, которая стала бы «сигналом для энергичных людей», способных обеспечить «стабильную растущую экономику». По подсчётам инициаторов амнистии, освободить от дальнейшего отбывания наказания подлежало 110924 человек, которые отбывали наказание за экономические преступления, распространив амнистию на 53 состава преступления. За амнистией должны были стоять идеи необходимости перевернуть страницу истории, написанную в «лихие» 1990-е гг., когда «правила игры были прописаны не в законах, а в понятиях», исключить уголовное преследование «по заказным делам» как способ «отъема собственности»; амнистия должна была бы стать «сигналом, что они (бизнесмены. $-A$. X.) нужны, что им можно открывать свое дело без страха оказаться за решеткой» ${ }^{4}$.

25 июня 2013 г. проект постановления об объявлении амнистии был внесён в Государственную Думу Президентом РФ. В пояснительной записке к проекту приводились лишь общие соображения без какой-либо подробной мотивировки необходимости объявления амнистии, и уже 2 июля 2013 г. проект был принят в трёх чтениях в течение одного дня.

Итоговая редакция постановления об объявлении амнистии предусматривала как освобождение от наказания, так и освобождение от уголовной ответственности лиц, совершивших ряд преступлений. В соответствии со сложившейся практикой освобождение от уголовной ответственности таких лиц предполагалось в случае, если уголовные дела в их отношении находились в производстве органов дознания, предварительного следствия и суда, т.е. в если в их отношении ещё не был вынесен приговор суда (пункт 5). Условием применения акта об амнистии выступало выполнение лицами, подозреваемыми и обвиняемыми в совершении соответствующих преступлений обязательств по возврату имущества и (или) возмещению убытков потерпевшим, и отсутствие препятствий к применению акта об амнистии, сформулированных в пункте 7 постановления. Кроме того, в соответствии с ч. 2 ст. 27 УПК РФ подозреваемый или обвиняемый должен был дать согласие на применение к нему акта амнистии; в противном случае производство по уголовному делу должно было продолжаться в обычном порядке, и в случае вынесения обвинительного приговора суд освобождал бы осужденного от наказания (ч. 8 ст. 302 УПК РФ).

Обобщив практику применения судами постановления об объявлении амнистии, Верховный Суд РФ осенью 2013 г. издал Обзор судебной практики по применению Федерального закона от 29 ноября 2012 г. № 207-Ф3 «О внесении изменений в Уголовный кодекс Российской Федерации и отдельные законодательные акты Российской Федерации» и постановления Государственной Думы Федерального Собрания Российской Федерации от 2 июля 2013 г. № 2559-6 ГД «Об объявлении амнистии»5.

Анализируя практику применения постановления об объявлении амнистии, хотелось бы отметить, что наиболее спорным моментом стало, что неудивительно, сформулированное в постановлении условие освобождения от уголовной ответственности - выполнение обязательства по возврату имущества и (или) возмещению убытков потерпевшим. Формально-юридическая предпосылка к применению постановления об амнистии, т.е. совершение одного из указанных в акте об амнистии преступлений, по нашему мнению, не имеет прямого отношения к проблематике освобождения от уголовной ответственности, поскольку связана с правильной квалификацией деяния органами предварительного расследования и судом.

Верховный Суд РФ предложил судам следующее понимание этого условия освобождения от уголовной ответственности. В соответствии с ч. 2 ст. 15 ГК РФ под убытками потерпевшим следует понимать расходы, которые лицо, чье право нарушено, произвело или должно будет произвести для восстановления нарушенного права, утрата или повреждение его имущества (реальный ущерб), а также неполученные доходы, которые это лицо получило бы при обычных условиях гражданского оборота, если бы его право не было нарушено (упущенная выгода). В целях правильного применения акта об амнистии судам необходимо устанавливать прежде всего наличие реального ущерба (вреда), предусмотренного в качестве признака преступления в статьях Особенной части УК РФ. Кроме того, суды должны обращать внимание и на возможность установления упущенной выгоды в тех случаях, когда она является признаком преступления (например, в ст. 146 УК РФ) или одним из требований гражданского истца. Реальный ущерб может быть возмещен в натуре (предоставление вещи того же рода и качества,

\footnotetext{
${ }^{4}$ Коммерсантъ. 2013. 8 мая. № 78(5109). $\quad \quad{ }^{5}$ СПС «КонсультантПлюс».
} 
DOI: $10.7256 / 1811-9018.2014 .10 .13075$

При цитировании этой статьи сноска на dоі обязательна

\section{Право и политика $10(178) \cdot 2014$}

ремонт или исправление поврежденного имущества), в денежной форме (возмещение стоимости утраченного или поврежденного имущества), путем компенсации неимущественных видов вреда (например, физического или морального вреда, вреда деловой репутации организации). Упущенная выгода возмещается посредством компенсации неполученных потерпевшим доходов.

При этом Верховный Суд РФ обоснованно подчеркнул два обстоятельства. Во-первых, в тех преступлениях, где криминообразующим признаком наряду с причинением крупного ущерба может выступать извлечение дохода в крупном размере, отсутствие ущерба при наличии дохода не исключает возможности применения постановления об объявлении амнистии. Например, в деле А., который обвинялся в незаконном предпринимательстве, сопряженном с извлечением дохода в особо крупном размере, потерпевших и гражданских истцов не было, убытки не были причинены. Уголовное дело было обоснованно прекращено ${ }^{6}$.

Во-вторых, даже при наличии криминообразующего признака в виде причинения крупного ущерба ввиду конкретной ситуации (например, покушения на преступление) последний может быть не причинён. И в этом случае Верховный Суд РФ предложил применять постановление об объявлении амнистии, поскольку в таких случаях у подсудимых отсутствуют обязательства по возврату имущества и (или) возмещению убытков потерпевшему. Например, в деле Ф., который обвинялся в покушении на мошенничество в сфере кредитования и был задержан на месте совершения преступления при попытке получить кредит по подложным документам, суд, учитывая, что материальный ущерб потерпевшему (банку) не причинен, поскольку преступление не было доведено до конца по независящим от Ф. обстоятельствам, уголовное дело в отношении обвиняемого прекратил ${ }^{7}$. Аналогичное решение было принято по делу Д., который был признан виновным в покушении на мошенничество в сфере кредитования, В 2013 г., получив от неустановленного соучастника паспорт на имя Б., он

\footnotetext{
${ }^{6}$ См.: п. 2.5.2 Обзора судебной практики по применению Федерального закона от 29 ноября 2012 г. № 207-ФЗ «О внесении изменений в Уголовный кодекс Российской Федерации и отдельные законодательные акты Российской Федерации» и постановления Государственной Думы Федерального Собрания Российской Федерации от 2 июля 2013 г. № 2559-6 ГД «Об объявлении амнистии».

${ }^{7}$ См.: п. 2.5.3 Обзора судебной практики по применению Федерального закона от 29 ноября 2012 г. № 207-Ф3 «О внесении изменений в Уголовный кодекс Российской Федерации и отдельные законодательные акты Российской Федерации» и постановления Государственной Думы Федерального Собрания Российской Федерации от 2 июля 2013 г. № 2559-6 ГД «Об объявлении амнистии».
}

предъявил его в качестве документа, удостоверяющего его, Д., личность, с целью получения потребительского кредита на сумму 58785 руб., после чего был задержан сотрудниками полиции. Апелляционная инстанция приговор суда отменила, а уголовное дело прекратила на основании акта об амнистии, указав, что акт амнистии вступил в силу до момента вынесения приговора, а Д. осужден за покушение на мошенничество в сфере кредитования, какое-либо имущество им похищено не было по не зависящим от него обстоятельствам, убытки потерпевшему не причинены (апелляционное постановление Московского городского суда от 30 октября 2013 г. № 10-10931 $1^{8}$ ).

Вместе с тем в том случае, когда в деле имеются обязательства по возврату имущества и (или) возмещению убытков потерпевшим, на практике может возникать довольно-таки спорная ситуация, связанная с оценкой стоимости возвращаемого имущества или размера возмещаемых убытков. Иными словами, оценка стоимости возвращаемого имущества или размера возмещаемых убытков может быть разной в понимании, с одной стороны, правоохранительного органа и потерпевшего и, с другой, подозреваемого или обвиняемого 9 . Фактически подозреваемый или обвиняемый ставится в зависимость от позиции органа предварительного расследования или потерпевшего лица и имеет мало процессуальных возможностей оспорить их видение размера убытков (ущерба). В рамках действующего уголовно-процессуального законодательства при исчерпании стороной защиты всех возможностей по оспариванию в ходе предварительного расследования вменяемого размера убытков (ущерба) остаётся только один выход - дожидаться переноса дела на судебную стадию, где и пытаться установить точный размер подлежащего возмещению вреда. Однако это не способствует эффективному применению акта об амнистии.

Попутно следует отметить, что эта же проблема может быть присуща амнистии и в том случае, если дело перенесено на судебную стадию по указанным причинам на основании ч. 2 ст. 27 УПК РФ. В таком случае амнистия, становясь уже видом освобождения от наказания, может быть «заблокирована» в ситуации, когда размер подлежащего возмещению вреда не установлен приговором суда, а гражданский иск передан на

\footnotetext{
${ }^{8}$ СПС «КонсультантПлюс».

${ }^{9}$ См.: Колоколов Н. Вот тебе, предприниматель, и Юрьев день... // ЭЖ-Юрист. 2013. № 33. С. 3; Почечуева О. С. Об определении вреда потерпевшим - юридическим лицам на предварительном следствии в свете «предпринимательской» амнистии // Адвокат. 2013. № 9.
} 
разрешение в рамках гражданского судопроизводства. Здесь фактически применение акта об амнистии может быть отложено на неопределённый срок, в особенности тогда, когда иск о возмещении вреда потерпевшими ещё не заявлен, а исковая давность по гражданскому законодательству не истекла. Примером этого может служить апелляционное постановление Московского городского суда от 12 марта 2014 г. № 10-3563/14 по делу Б.В., в котором в применении амнистии было отказано по тем причинам, что осуждённым по ч. 2 ст. $159^{1}$ УК РФ ущерб не возмещён. Ссылка лица на то, что приговором суда размер ущерба не определён, а за банком признано право на удовлетворении иска, вопрос о размере возмещения передан для рассмотрения в порядке гражданского судопроизводства, была признана не имеющей юридического значения, поскольку, по мнению апелляционной инстанции, факт причинения ущерба установлен приговором, а банк может обратиться с иском в установленном законом порядке в пределах срока исковой давности ${ }^{10}$. В этом деле, таким образом, применение амнистии откладывается на достаточно долгий срок по причинам, не зависящим от воли осуждённого лица, и эффект амнистии как вида освобождения от уголовной ответственности и наказания оказывается нивелирован необходимостью исполнения последнего вплоть до принятия в итоге решения о применении амнистии (например, в приведённом деле к лицу было применено условное осуждение, и очевидно, что вплоть до освобождения на основании акта амнистии оно обязано претерпевать ограничения, связанные с испытательным сроком).

Представляется, что в данном своём аспекте постановление об объявлении амнистии не согласуется с предъявляемым к амнистии требованием со стороны Конституционного Суда РФ, в соответствии с которым «условия амнистии не могут формулироваться таким образом, чтобы ими допускалось произвольное ее применение» (постановление Конституционного Суда РФ от 5 июля 2001 г. № 11-П по делу о проверке конституционности Постановления Государственной Думы от 28 июня 2000 года № 492-III ГД «О внесении изменения в Постановление Государственной Думы Федерального Собрания Российской Федерации «Об объявлении амнистии в связи с 55-летием Победы в Великой Отечественной войне 1941-1945 годов» в связи с запросом Советского районного суда города Челябинска и жалобами ряда граждан $\left.{ }^{11}\right)$.

\footnotetext{
${ }^{10}$ СПС «КонсультантПлюс».

${ }^{11}$ Собрание законодательства РФ. 2001. № 29. Ст. 3059.
}

Критически оценивается практика амнистирования на этапе предварительного расследования и в литературе именно потому, что в этих случаях расследование становится менее качественным ${ }^{12}$. (Один из самых серьёзных доводов против такой практики, связанный с действием ст. 49 Конституции РФ, требует отдельного анализа.) Более того, определённая справедливость имеется и в суждении, согласно которому «применение амнистии не должно ставиться в зависимость от возмещения виновными причиненного материального ущерба, поскольку амнистируемое лицо зачастую не может в момент принятия решения об амнистии возместить вред или ущерб, такие лица будут в худшем положении по сравнению с относительно обеспеченными» ${ }^{13}$.

По изложенным причинам неудивительно, что амнистия как вид освобождения от уголовной ответственности за преступления в сфере предпринимательской деятельности состоялась в очень ограниченном масштабе. По данным, приведённым Верховным Судом Р $\Phi^{14}$, на 1 октября 2013 г. судами были прекращены уголовные дела или приняты решения об освобождении от наказания в отношении 401 лица, подсудимых или осужденных по: ст. 146 УК РФ (91 лицо); ст. $159^{1}$ УК РФ (149 лиц); ст. $159^{4}$ УК РФ (15 лиц); ст. 171 УК РФ (63 лица); ст. 180 УК РФ (14 лиц); ст. 191 УК РФ (14 лиц); ст. 199 УК РФ (10 лиц); ст. $199^{2}$ УК РФ (12 лиц). В результате рассмотрения 88 ходатайств судами отказано в применении постановления об амнистии, при этом 74 лицам отказано ввиду того, что обвиняемым или осужденным не было исполнено обязательство по возврату имущества и (или) возмещению убытков потерпевшим. По данным Центра общественных процедур «Бизнес против коррупции», по состоянию на 20 марта 2014 г. число лиц, в отношении которых было применено постановление Государственной Думы «Об объявлении амнистии», составило 2314 человек ${ }^{15}$.

\footnotetext{
${ }^{12}$ См., например: Петрухин И. Л. Презумпция невиновности конституционный принцип советского уголовного процесса. // Советское государство и право. 1978. № 12. С. 23; Марогулова И. Л. Законодательные проблемы амнистии и помилования // Журнал российского права. 1998. № 1. С. 42.

${ }^{13}$ Осмоловская Н. В. Амнистия и помилование как средства корректирования карательной политики государства: автореф. дис. ... канд. юрид. наук. Тюмень, 2006. С. 16.

${ }^{14}$ См.: Обзор судебной практики по применению Федерального закона от 29 ноября 2012 г. № 207-Ф3 «О внесении изменений в Уголовный кодекс Российской Федерации и отдельные законодательные акты Российской Федерации» и постановления Государственной Думы Федерального Собрания Российской Федерации от 2 июля 2013 г. № 2559-6 ГД «Об объявлении амнистии».

${ }^{15}$ См.: http://ombudsmanbiz.ru/2014/02/5410.html
} 
DOI: $10.7256 / 1811-9018.2014 .10 .13075$

При цитировании этой статьи сноска на доі обязательна

\section{Право и политика $10(178) \cdot 2014$}

Таким образом, в отношении только около 2 тысяч человек амнистия была применена как вид освобождения от уголовной ответственности, что очевидно не согласуется с её заявленными целями.

По нашему мнению, причина здесь кроется в глубоко ошибочном подходе к использованию амнистии как вида освобождения от уголовной ответственности в данном случае. В литературе подчёркивается, что амнистия представляет собой реализацию принципа гуманизма ${ }^{16}$ и не должна служить корректировке уголовного закона ${ }^{17}$ или ставить под сомнение вынесенный приговор суда ${ }^{18}$.

«Экономическая амнистия» же её инициаторами изначально рассматривалась, напомним их слова, как способ дать обществу позитивный экономический сигнал, исключить нарушения в применении уголовного закона по так называемым «заказным делам». Иными словами, амнистия должна была бы стать компенсаторным механизмом, смягчающим строгость уголовного закона или устраняющим его необоснованное применение. Однако такой взгляд на амнистию противоречит её сути - применяя амнистию, государство ориентировалось не на виновных лиц, а на общество и само себя прежде всего; гуманизм в отношении привлекаемых к уголовной ответственности уступил место политическим интересам. Нельзя не отметить, что о таком неверном понимании амнистии писал ещё Чезаре Беккариа, по мнению которого практика амнистии, или прощения, не может существовать «в совершенном законодательстве, где наказания умеренны, а суд праведен и скор. Эта истина покажется суровой тому, кто живет в стране с неупорядоченной системой уголовного законодательства. А потому в этой стране потребность в прощении и милосердии прямо зависит от нелепости законов и суровости приговоров» ${ }^{19}$.

По нашему мнению, «экономическая амнистия» в своих краткосрочных последствиях, для тех двух тысяч человек, которых она коснулась, стала несомненно позитивным явлением, поскольку таковым действительно является любое смягчение уголовно-правовых последствий совершённого деяния. Однако рассматриваемая в целом, амнистия была глубоко ошибочным шагом. Вместо предполагаемой необходимости изменения уголовного закона в сторону его смягчения (что также требует отдельного обсуждения), вместо исправления судебных ошибок государство избрало путь одноразового исправления. Однако где гарантия того, что подобная амнистия не потребуется через несколько лет вновь? И если такое случится, то не перестанет ли амнистия отвечать своей сути, превратившись в средство исправления уголовного законодательства. Итак, резюмируя сказанное, нельзя не отметить ошибочности подхода к амнистии как к средству исправления содержательных и правоприменительных недостатков уголовного закона. Последние должны корректироваться существующими методами, т.е. законотворчеством и правоприменением.

\section{Библиография:}

1. Беккариа Ч. О преступлениях и наказаниях. М., 1995. 303 с.

2. Васильева И. А. Амнистия и ее реализация: автореф. дис. ... канд. юрид. наук. Омск, 2003. 24 с.

3. Колоколов Н. Вот тебе, предприниматель, и Юрьев день... // ЭЖ-Юрист. 2013. № 33. С. 3.

4. Комольцева А. А., Ивашкина Е. А. Институт амнистии: правовая природа и проблемы применения в современной России // Уголовно-исполнительная система: право, экономика, управление. 2012. № 3. С. 22-25.

5. Марогулова И. Л. Законодательные проблемы амнистии и помилования // Журнал российского права. 1998. № 1. С. $38-44$.

6. Осмоловская Н. В. Амнистия и помилование как средства корректирования карательной политики государства: автореф. дис. ... канд. юрид. наук. Тюмень, 2006. 18 с.

7. Осяк А. Н. Институт амнистии в российском уголовном праве: автореф. дис. ... канд. юрид. наук. Ростов-н/Д., 2006. 26 с.

8. Петрухин И. Л. Презумпция невиновности - конституционный принцип советского уголовного процесса. // Советское государство и право. 1978. № 12. С. 18-26.

9. Почечуева О. С. Об определении вреда потерпевшим - юридическим лицам на предварительном следствии в свете «предпринимательской» амнистии // Адвокат. 2013. № 9. С. 5-9.

\footnotetext{
${ }^{16}$ См., например: Комольиева А. А., Ивашкина Е. А. Институт амнистии: правовая природа и проблемы применения в современной России // Уголовно-исполнительная система: право, экономика, управление. 2012. № 3. С. 22.

${ }_{17}$ См., например: Васильева И. А. Амнистия и ее реализация: автореф. дис. ... канд. юрид. наук. Омск, 2003. С. 6.

${ }^{18}$ См., например: Осяк $A$. Н. Институт амнистии в российском уголовном праве: автореф. дис. ... канд. юрид. наук. Ростов-н/Д., 2006. C. 9.
}

${ }^{19}$ Беккариа Ч. О преступлениях и наказаниях. М., 1995. С. 243-244. 
10. Т. М. Секретарева. К вопросу о возможности ограничения права на амнистию. // Политика и Общество. - 2010. - № 9.

11. Протопопова Н.И.. Налоговая амнистия как институт экономической политики государства: российская практика // Налоги и налогообложение. - 2008. - № 3

12. Салказанов А.Э. Актуальные вопросы совершенствования уголовной ответственности за уклонение от уплаты налогов и (или) сборов с организации в РФ (ст.199 УК РФ) // Налоги и налогообложение. - 2014. - 3. - C. 336 - 342. DOI: 10.7256/1812-8688.2014.3.11487.

13. Букалерова Л.А., Шельменкова Я.Ю. К вопросу об освобождении от уголовной ответственности в связи с истечением сроков давности // Административное и муниципальное право. - 2013. - 9. - С. 910 - 916. DOI: 10.7256/1999-2807.2013.9.8966.

14. Токарчук Р.Е. Общественная опасность как общий принцип уголовного права и уголовной ответственности // NB: Вопросы права и политики. - 2012. - 1. - C. 126 - 142. URL: http://www.e-notabene.ru/lr/article_51.html

15. Антонова Е.Ю. Уголовная ответственность корпоративного (коллективного) субъекта за коррупционные преступления // NB: Вопросы права и политики. - 2013. - 3. - C. 192 -220. DOI: 10.7256/2305-9699.2013.3.568. URL: http://www.e-notabene. $\mathrm{ru} / \mathrm{lr} /$ article 568.html

16. Салказанов А.Э. Уголовная ответственность за уклонение от уплаты налогов и (или) сборов в Российской Федерации и зарубежных странах на примере ответственности организаций. // Налоги и налогообложение. - 2013. - 11. - С. 852 - 859. DOI: $10.7256 / 1812-8688.2013 .11 .9961$.

17. Кашкина Е.В., Хандогина А.В. Административный надзор за лицами, освобожденными из мест лишения свободы: проблемы правоприменительной практики // Полицейская деятельность. - 2013. - 6. - С. 375 - 379. DOI: 10.7256/22221964.2013.6.10133.

18. Долгих И.П., Шебанов Д.В. Об оптимизации понятия «хищение» в российском законодательстве // NB: Вопросы права и политики. -2014. - 5. - C. 23 - 37. DOI: 10.7256/2305-9699.2014.5.11933. URL: http://www.e-notabene.ru/lr/article_11933.html

19. М.О. Акопджанова Диспозиции норм уголовного законодательства России о налоговых преступлениях: вопросы разграничения составов // Национальная безопасность / nota bene. - 2012. - 6. - С. 105 - 109.

\section{References (transliterated):}

1. Bekkaria Ch. O prestupleniyakh i nakazaniyakh. M., 1995. $303 \mathrm{s.}$

2. Vasil'eva I. A. Amnistiya i ee realizatsiya: avtoref. dis. ... kand. yurid. nauk. Omsk, 2003. 24 s.

3. Kolokolov N. Vot tebe, predprinimatel', i Yur'ev den'... // EZh-Yurist. 2013. № 33. S. 3.

4. Komol'tseva A. A., Ivashkina E. A. Institut amnistii: pravovaya priroda i problemy primeneniya v sovremennoi Rossii // Ugolovno-ispolnitel'naya sistema: pravo, ekonomika, upravlenie. 2012. № 3. S. 22-25.

5. Marogulova I. L. Zakonodatel'nye problemy amnistii i pomi-lovaniya // Zhurnal rossiiskogo prava. 1998. № 1. S. $38-44$.

6. Osmolovskaya N. V. Amnistiya i pomilovanie kak sredstva korrek-tirovaniya karatel'noi politiki gosudarstva: avtoref. dis. ... kand. yurid. nauk. Tyumen', 2006. $18 \mathrm{~s}$.

7. Osyak A. N. Institut amnistii v rossiiskom ugolovnom prave: avtoref. dis. ... kand. yurid. nauk. Rostov-n/D., 2006. $26 \mathrm{~s}$

8. Petrukhin I. L. Prezumptsiya nevinovnosti - konstitutsionnyi printsip sovetskogo ugolovnogo protsessa. // Sovetskoe gosudarstvo i pravo. 1978. № 12. S. 18-26.

9. Pochechueva O. S. Ob opredelenii vreda poterpevshim - yuridiche-skim litsam na predvaritel'nom sledstvii v svete «predprinimatel'skoi» amnistii // Advokat. 2013. № 9. S. 5-9.

10. T. M. Sekretareva. K voprosu o vozmozhnosti ogranicheniya prava na amnistiyu. // Politika i Obshchestvo. - 2010. - № 9.

11. Protopopova N.I.. Nalogovaya amnistiya kak institut ekonomicheskoi politiki gosudarstva: rossiiskaya praktika // Nalogi i nalogooblozhenie. - 2008. - № 3

12. Salkazanov A.E. Aktual'nye voprosy sovershenstvovaniya ugolovnoi otvetstvennosti za uklonenie ot uplaty nalogov i (ili) sborov s organizatsii v RF (st.199 UK RF) // Nalogi i nalogooblozhenie. -2014. - 3. - C. 336 - 342. DOI: 10.7256/1812-8688.2014.3.11487.

13. Bukalerova L.A., Shel'menkova Ya.Yu. K voprosu ob osvobozhdenii ot ugolovnoi otvetstvennosti v svyazi s istecheniem srokov davnosti // Administrativnoe i munitsipal'noe pravo. - 2013. - 9. - C. 910 - 916. DOI: 10.7256/1999-2807.2013.9.8966.

14. Tokarchuk R.E. Obshchestvennaya opasnost' kak obshchii printsip ugolovnogo prava i ugolovnoi otvetstvennosti // NB: Voprosy prava i politiki. - 2012. - 1. - C. 126-142. URL: http://www.e-notabene.ru/lr/article_51.html

15. Antonova E.Yu. Ugolovnaya otvetstvennost' korporativnogo (kollektivnogo) sub"'ekta za korruptsionnye prestupleniya // NB: Voprosy prava i politiki. - 2013.-3.-C. 192 -220. DOI: 10.7256/2305-9699.2013.3.568. URL: http://www.e-notabene.ru/lr/article_568.html

16. Salkazanov A.E. Ugolovnaya otvetstvennost' za uklonenie ot uplaty nalogov i (ili) sborov v Rossiiskoi Federatsii i zarubezhnykh stranakh na primere otvetstvennosti organizatsii. // Nalogi i nalogooblozhenie. - 2013. - 11. - C. 852 - 859. DOI: 10.7256/18128688.2013.11.9961.

17. Kashkina E.V., Khandogina A.V. Administrativnyi nadzor za litsami, osvobozhdennymi iz mest lisheniya svobody: problemy pravoprimenitel'noi praktiki // Politseiskaya deyatel'nost'. - 2013. - 6. - C. 375 - 379. DOI: 10.7256/2222-1964.2013.6.10133.

18. Dolgikh I.P., Shebanov D.V. Ob optimizatsii ponyatiya "khishchenie" v rossiiskom zakonodatel'stve // NB: Voprosy prava i politiki. - 2014. - 5. - C. 23 - 37. DOI: 10.7256/2305-9699.2014.5.11933. URL: http://www.e-notabene.ru/lr/article_11933.html

19. M.O. Akopdzhanova Dispozitsii norm ugolovnogo zakonodatel'stva Rossii o nalogovykh prestupleniyakh: voprosy razgranicheniya sostavov // Natsional'naya bezopasnost' / nota bene. - 2012. - 6. - C. $105-109$. 